\title{
„Z CZLOWIEKA POWSTAJE BÓG”. TERMINOLOGIA PRZEBÓSTWIENIA W PISMACH ŚW. GRZEGORZA Z NYSSY
}

W pismach wczesnochrześcijańskich wiodącą koncepcję życia duchowego, wyrażającą zależność uczestnictwa bytu stworzonego w Stwórcy, stanowiła doktryna przebóstwienia człowieka ${ }^{1}$. W jej ramach starożytni autorzy ujmowali ,złotą regułę soteriologii patrystycznej”2, która swój punkt szczytowy osiągnęła w misterium inkarnacji Słowa Bożego, co też oddaje krótka maksyma św. Atanazego: „Ono bowiem wcieliło się, abyśmy my zostali przebóstwieni"’3. W ten bogaty nurt Kościoła Wschodniego wpisuje się także św. Grzegorz z Nyssy, który - jak zaznacza David L. Balás - świadomie ogranicza

${ }^{*}$ Mgr Agnieszka Wyrąbkiewicz - doktorantka przy Zakładzie Historii Kościoła - Starożytnej i Średniowiecznej na Wydziale Teologicznym Uniwersytetu Mikołaja Kopernika w Toruniu; e-mail: wyrabkiewicz@o2.pl.

${ }^{1}$ Termin $\theta \varepsilon ́ \omega \sigma \iota \varsigma$ (czy $\left.\theta \varepsilon \omega \pi \circ i ́ \eta \sigma ı \varsigma\right)$ funkcjonujący w przedchrześcijańskiej kulturze klasycznej został zaadoptowany dla potrzeb duchowości wczesnochrześcijańskiej dzięki pismom Klemensa Aleksandryjskiego, choć sama myśl wiążąca się z ideą deifikacji pojawia się już u Ojców Apostolskich. W ten sposób, nie bez świadomości zagrożenia płynącego z pogańskich inklinacji idei deifikacji, Ojcowie wyrażali wielką godność człowieka, powołanego w momencie aktu stwórczego do wejścia na Boży poziom życia, przy jednoczesnym zachowaniu teologii apofatycznej, akcentującej istotową różnicę między naturą Bytu Odwiecznego a naturą bytu stworzonego. Wypływające z pogańskiego pochodzenia owej doktryny niebezpieczeństwo wywarło jednak zasadniczy wpływ na używaną przez Ojców Kościoła terminologię, stąd znacznie częściej posługiwali się oni pojęciami opisowymi (m.in. pokrewieństwo z Bogiem, zażyłość, wspólnota, zespolenie, uczestnictwo w Bogu) - por. Eckmann, Przebóstwienie człowieka, s. 72-74; J.W. Żelazny, Patrystyczna doktryna o powołaniu czlowieka do udziału w życiu i godności Boga. Rola Ducha Świętego, TPatr 3 (2006) 60; T. Špidlik - I. Gargano - V. Grossi, Duchowość Ojców Kościoła, t. 3, Kraków 2004, 47; B. Częsz, Jesteśmy z Jego rodu (Dz 17, 28). Nasza teraźniejszość jako antycypowane doświadczenie przebóstwienia w świetle tradycji patrystycznej, w: Ad sapientiam cordis. Księga pamiątkowa dedykowana ks. prof. Ludwikowi Gładyszewskiemu w 70. rocznicę urodzin, red. P. Podeszwa - W. Szczerbiński, Gniezno 2002, 31.

${ }^{2}$ J. Naumowicz, Wcielenie Boga i zbawienie człowieka. Złota reguła soteriologii patrystycznej, WST 13 (2000) 17.

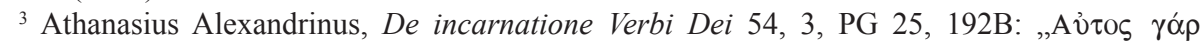

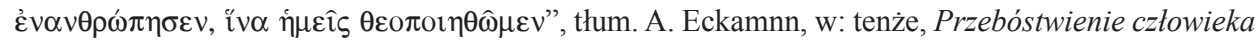
w pismach wczesnochrześcijańskich, Lublin 2003, 153. 
się do wyraźnej nauki ${ }^{4}$, co wiąże się ze stosunkowo rzadko używaną przez niego terminologią przebóstwienia. Mimo to, wśród grona badaczy duchowej spuścizny Nysseńczyka, kilku ${ }^{5}$ nie wahało się określić go głównie jako propagatora doktryny deifikacji. Zasadnym więc jawi się pytanie o językowe narzędzia służące do wyrażenia schematu przebóstwienia, stąd niniejszy artykuł stawia sobie za cel scharakteryzowanie podstawowej siatki terminologicznej procesu $\theta \dot{\varepsilon} \omega \sigma ı \varsigma^{6}$ stosowanej przez św. Grzegorza z Nyssy, Kapadockiego filozofa i mistyka ${ }^{7}$.

\section{CZASOWNIKOWE WYRAŻENIA DEIFIKACJI VS. TEOLOGIA APOFATYCZNA}

Szczególnie ważne miejsce w pismach Grzegorza dotyczących deifikacji zajmują wyrażenia czasownikowe: $\theta \varepsilon o \pi$ oté $\omega, \theta \varepsilon o ́ \omega$ oraz $\sigma v v \alpha \pi \circ \theta \varepsilon o ́ \omega$, ponieważ Nysseńczyk, zachowując ortodoksyjną apofatyczną teologię Wschodu, nigdy nie używa terminu „przebóstwienie” ( $\theta \dot{\varepsilon} \omega \sigma ı \varsigma$ czy $\left.\theta \varepsilon \omega \pi \operatorname{cí}_{\eta} \sigma \iota \varsigma\right)$ w sposób dosłowny, rzeczownikowy ${ }^{8}$. Wśród trzech wyżej wymienionych czasowników, tworzących trzon siatki pojęciowej przebóstwienia u Kapadocczyka, jeden odnosi się wyłącznie do aspektu chrystologicznego deifikacji

${ }^{4}$ Por. D.L. Balás, Deification, w: The Brill Dictionary of Gregory of Nyssa, ed. L.F. Mateo-Seco - G. Maspero, VigCh Supplements 99, Leiden 2010, 210-213.

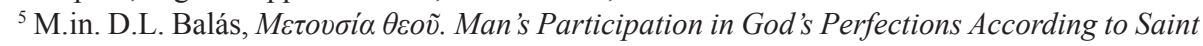
Gregory of Nyssa, Studia Anselmiana 55, Rome 1966; tenże, Christian Transformation of Greek Philosophy Illustrated by Gregory of Nyssa's Use of the Notion of Participatuion, „Proceedings of the American Catholic Philosophical Association” 40 (1966) 152-157; B.E. Daley, ,Heavenly Man” and "Eternal Christ”: Apollinarius and Gregory of Nyssa on the Personal Identity of the Savior, JECS 10 (2002) 469-488. Por. N. Russell, The doctrine of deification in the Greek patristic tradition, Oxford 2006, 226.

${ }^{6} \mathrm{Na}$ temat aspektu trynitarnego, chrystocentrycznego i antropologicznego, epektazy lub zarysowania idei deifikacji na tle apofatycznego nauczania Nysseńczyka zob. Daniélou, Platonisme et théologie mistique; Balás, Deification, s. 210-213; J. Rother, Gottverähnlichung als ein Weg zur Gotteinigung beim hl. Gregor von Nyssa, w: Gregory of Nyssa, Homilies on the Beatitudes, ed.

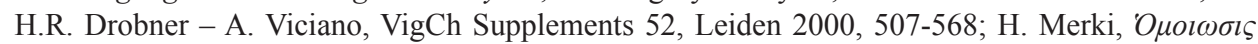
$\Theta \varepsilon \omega$ : von der platonischen Angleichung an Gott zur Gottähnlichkeit bei Gregor von Nyssa, Freiburg in der Schweiz 1952; W. Szczerba, A Bóg będzie wszystkim we wszystkim... Apokatastaza Grzegorza z Nyssy: tło, źródła, ksztalt koncepcji, Kraków 2008; tenże, Problem przebóstwienia na tle apofatycznej teologii Grzegorza z Nyssy, „Filozofia religii” 5 (2009) 283-299; M. Przyszychowska, Nauka o tasce w dziełach świętego Grzegorza z Nyssy, Kraków 2010. Również E. Kotkowska (Pomyśleć świat jako całość) rozważa problem przebóstwienia wobec makro- i mikrokosmosu.

${ }^{7}$ Por. J. Daniélou, Platonisme et théologie mistique. Essai sur la doctrine spirituelle de saint Grégoire de Nysse, Paris 1944, 6; F. Drączkowski, Grzegorz z Nyssy, EK VI 316-320; R. Tichy, Tajemnicza natura Grzegorza z Nyssy (Poczet mistyków chrześcijańskich), „Fronda” 13/14 (1998) 441-459; E. Kotkowska, Pomyśleć świat jako całość wedlug św. Grzegorza z Nyssy, Poznań 2003, 13; P. Szczur, ,Święć się Imię Twoje” w wyktadzie św. Grzegorza z Nyssy, w: Modlitwa uwielbienia, red. J. Misiurek - J. Popławski - K. Burski, Homo orans V, Lublin 2004, 296.

${ }^{8}$ Por. Balás, Deification, s. 210-213. 
- $\sigma v v \alpha \pi \circ \theta \varepsilon o ́ \omega$, zaś zakres dwóch pozostałych terminów poszerzony został również do aspektu antropologicznego, opisanego głównie za pomocą cnót złożonych w człowieku, mających istotny wpływ na progres przebóstwienia:

- $\theta \varepsilon \circ \pi 01 \varepsilon ́ \omega$ - „,zynić bogiem”, „przebóstwiać”, „ubóstwiać” (w pismach Grzegorza pojawia się 10 razy $^{9}$ );

- $\theta \varepsilon o ́ \omega-$, ,przebóstwiać”, „ubóstwiać” (występuje $1 \mathrm{raz}^{10}$ );

- $\sigma v v \alpha \pi \circ \theta \varepsilon o ́ \omega$ - „przebóstwiać z sobą”, „wespół ubóstwiać”, „współprzebóstwiać" (występuje 3 razy $^{11}$ ).

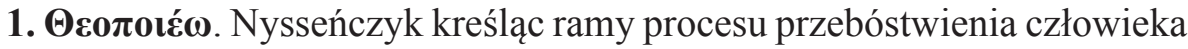
posługiwał się przede wszystkim czasownikiem $\theta \varepsilon \circ \pi$ oté $\omega$, który we wczesnych pismach Autora występuje tylko jeden raz ${ }^{12}$. Chcąc ukazać wartość czystości duszy, Grzegorz podkreśla dynamizm działania cnoty w człowieku, która - stając się katalizatorem wewnętrznego procesu oczyszczenia zamazanego przez grzech obrazu Bożego - powoduje wzrost uczestnictwa duszy $\mathrm{w}$ atrybutach będących właściwymi przymiotami Boga ${ }^{13}$ :

„[...] kto dostępuje udziału w tajemnicy czystości, w jakiś sposób zostaje

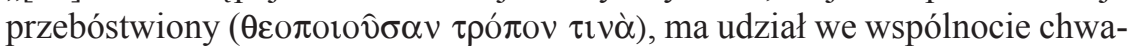
ły jedynego prawdziwie świętego i niewinnego Boga"14.

Dzięki takiemu zaprezentowaniu koncepcji cnoty czystości Kapadocczyk wyraża deifikację w sensie analogicznym, jako duchową zależność bytu stworzonego od niezmiennej, świętej natury Boga. Powyższy fragment nie stanowi jednak wyczerpującego opisu podnoszenia natury ludzkiej ku boskości, ponie-

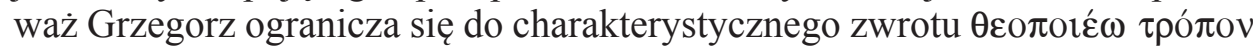

${ }^{9}$ Por. Gregorius Nyssenus, De virginitate, ed. J.P. Cavarnos, GNO 8/1, Leiden 1952, 252; tenże, De beatitudinibus or. 5, ed. J.F. Callahan, GNO 7/2, Leiden 1992, 124; tenże, Adversus Macedonianos de Spiritu Sancto, ed. F. Müller, GNO 3/1, Leiden 1958, 113; tenże, In Ecclesiasten hom. 8, ed. P. Alexander, GNO 5, Leiden 1962, 428 (2x); tenże, Contra Eunomium I, ed. W. Jaeger, GNO 1, 256,

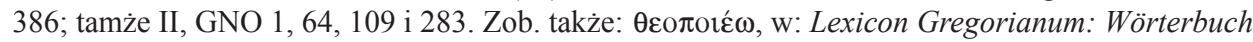
zu den Schriften Gregors von Nyssa, ed. F. Mann, t. 4, Leiden - Boston 2002, 229-239.

${ }^{10}$ Por. Gregorius Nyssenus, De beneficentia, ed. A. Van Heck, GNO 9, Leiden 1967, 103.

${ }^{11}$ Por. tenże, Oratio catechetica magna, ed. E. Mühlenberg, GNO 3/4, Leiden 1996, 86 i 97;

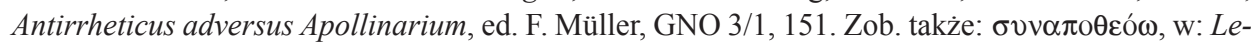
xicon Gregorianum: Wörterbuch zu den Schriften Gregors von Nyssa, ed. F. Mann, t. 8, Leiden Boston 2010, s. 316.

${ }^{12}$ Por. tenże, De virginitate, GNO 8/1, 21.

${ }^{13} \mathrm{~W}$ traktacie tym Grzegorz wychwala stan dziewiczy duszy, czyli wewnętrzną postawę czystości serca, która stanowi podstawę łączności w drodze deifikacji pomiędzy człowiekiem a Bogiem. Cnota ta nie odnosi się wyłącznie do aspektu cielesnego, lecz określa duchową kondycję człowieka, uwolnienie serca, dlatego jej uzyskanie możliwe będzie także poprzez praktykę filozofii. Por. Russell, The doctrine of deification, s. 226.

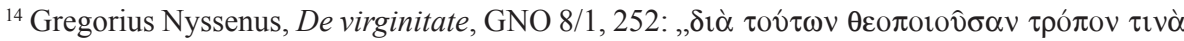

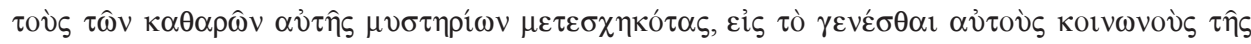

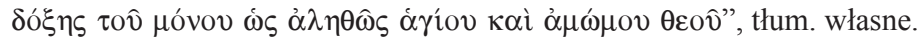




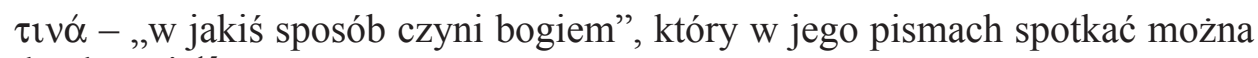
dwukrotnie ${ }^{15}$.

Ponowne użycie czasownika $\theta \varepsilon o \pi o t \varepsilon ́ \omega, \mathrm{z}$ zauważalnie większą częstotliwością, powraca w traktacie Contra Eunomium ${ }^{16}$, w którym Kapadocczyk posłużył się terminologią deifikacji w kontekście apologetycznym, aplikując wskazane pojęcie wyłącznie w znaczeniu negatywnym ${ }^{17}$. Szczególna krytyka terminu $\theta \varepsilon \circ \pi$ oté $\omega$ skierowana została wobec heretyckich twierdzeń Euno-

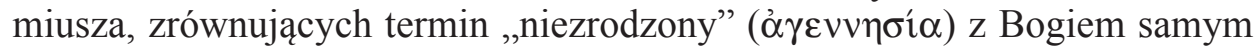

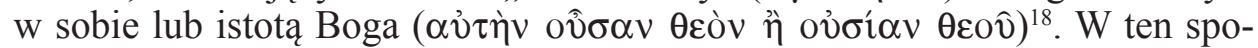
sób Grzegorz wykazuje błąd myślowy Eunomiusza, kwestionującego Bóstwo zrodzonego Syna Bożego ${ }^{19}$ i przyznającego samemu słowu ó $\gamma \varepsilon v v \eta \sigma i \alpha$ moc przebóstwiającą, m.in:

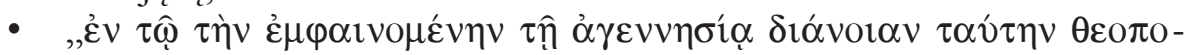
$દ \hat{\imath} v$ (w swoim twierdzeniu, że [słowo] niezrodzony czyni bogiem)"'20;

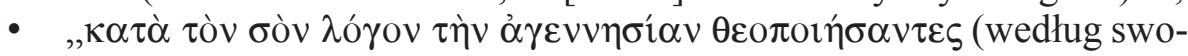
ich zasad [ze słowa] niezrodzony zrobili boga)" ${ }^{21}$.

W późniejszych pismach Nysseńczyka (głównie w De beatitudinibus) termin $\theta \varepsilon o \pi$ oté $\omega$ powiązany został z działaniem odnoszącym się do człowieka, a Grzegorz dla podkreślenia prawowierności swojej doktryny coraz częściej łączy w nich pojęcia związane $\mathrm{z}$ deifikacją zestawiając je $\mathrm{z}$ językiem udziału ${ }^{22}$

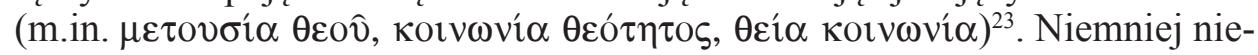

${ }^{15}$ Por. tamże; tenże, De beatitudinibus or. 5, GNO 7/2, 124. Zob. Russell, The doctrine of deification, s. 225-229.

${ }^{16}$ Czasownik $\theta \varepsilon o \pi$ eś $\omega$ pojawia się pięciokrotnie: Contra Eunomium II, GNO 1, 256, 386; Contra Eunomium III, ed. W. Jaeger, GNO 2, Leiden 1960, 64, 109 i 283.

${ }^{17}$ Por. Balás, Deification, s. 211.

${ }^{18}$ Gregorius Nyssenus, Contra Eunomium II, GNO 1, 256.

${ }^{19} \mathrm{~W}$ obronie Boskiej natury Chrystusa przeciw kontrowersji ariańskiej Grzegorz (Contra Eunomium II, GNO 1, 228) ukazuje równość Osób Boskich, za pomocą formuły, która potwierdzo-

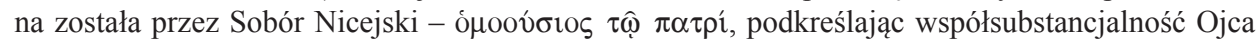
i Syna. Por. S. Strękowski, Sofiologia św. Grzegorza z Nyssy. Elementy teologii trynitarnej i antropologii w „Homiliach do Pieśni nad Pieśniami”, Kraków 2006, 127.

${ }^{20}$ Gregorius Nyssenus, Contra Eunomium II, GNO 1, 256: , ,

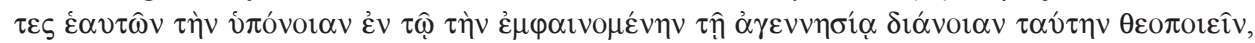

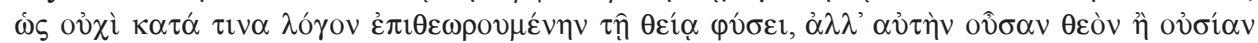
$\theta \varepsilon \circ \hat{v}$ ", thum. własne.

${ }^{21}$ Tamże, GNO 1, 386, tłum. własne.

${ }^{22}$ Terminologia partycypacji w Bogu przenika trzy główne dzieła Grzegorza o charakterze mistycznym: De vita Moysis, In Canticum canticorum oraz De beatitudinibus; por. M. Ludlow, Divine infinity and eschatology: the limits and dynamics of human knowledge, according to Gregory of Nyssa (CE II, 67-170), w: Contra Eunomium II, An English Version with Supporting Studies Proceedings of the $10^{\text {th }}$ International Colloquium on Gregory of Nyssa (Olomouc, September 15-18, 2004), ed. L. Karfíková - S. Douglass - J. Zachhuber, VigCh Supplements 82, Leiden 2007, 234.

${ }^{23}$ M.in. Gregorius Nyssenus, De virginitate, GNO 8/1, 252; tenże, Oratio catechetica magna, GNO 3/4, 22; De beatitudinibus or. 5, GNO 7/2, 124. Zob. także: Balás, Deification, s. 210-213; 
którzy badacze uważają, że Kapadocczyk unika bezpośredniego stosowania terminologii uczestnictwa wobec kategorii przebóstwienia, by nie dopuścić do zatarcia granic transcendencji niestworzonego Boga ${ }^{24}$. Równocześnie we współczesnych analizach pism Grzegorza akcentuje się istnienie głębokiej więzi między ideą partycypacji w Bogu a przebóstwieniem człowieka, jako dalszego etapu jej rozwoju ${ }^{25}$, czemu zostanie poświęcony trzeci punkt niniejszego artykułu.

Odrębny wariant czasownika $\theta \varepsilon$ cotóc $\omega$ Grzegorz rozważa w homilii 8. In Ecclesiasten $^{26}$, zestawiając koncepcję deifikacji wobec ludzkich pożądliwości, które zajmując w życiu człowieka miejsce należne wyłącznie Bogu, same stają się bożkami. Chcąc podkreślić pejoratywny sens idolatrii i absolutyzowania przyjemności w życiu ludzkości ${ }^{27}$, Autor posłużył się także bogatym językiem opisowym:

- „wprowadzamy przeciwieństwo Boga w Jego miejsce, czyniąc z na-

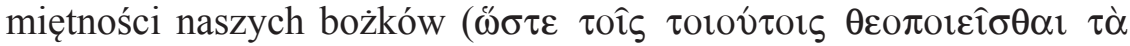
$\pi \alpha ́ \theta \eta)$.

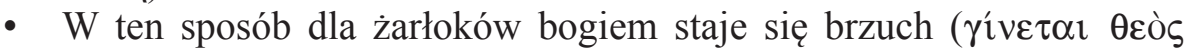

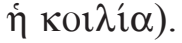

- $\quad[\ldots] \mathrm{Ci}$, którzy w tym życiu mają oczy duszy przesłonięte ciemnością

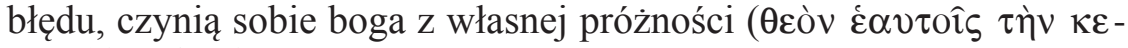

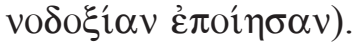

- Krótko mówiąc, jeśli ktoś poddaje swój umysł i czyni go niewolnikiem jakiejś rzeczy, poprzez własną namiętność czyni z tej rzeczy bożka

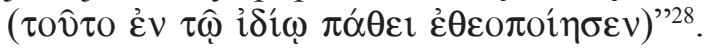

Ostatnia kategoria zastosowania czasownika $\theta \varepsilon o \pi o t \varepsilon ́ \omega$ w pismach Kapadocczyka dotyczy zestawienia koncepcji deifikacji z działaniem właściwym Duchowi Świętemu w traktacie Adversus Macedonianos de Spiritu Sancto ${ }^{29}$. Nysseńczyk podaje tu krótki katalog ekonomii Ducha Świętego wobec natury

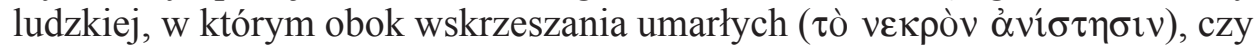

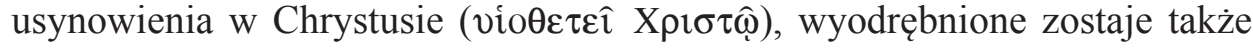

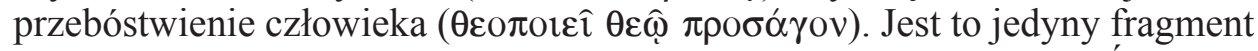
zastosowania terminu czasownikowego deifikacji wobec Ducha Świętego w pismach Autora ${ }^{30}$, czym poświadczone zostaje Bóstwo Trzeciej Osoby Trój-

tenże, Participation, w: The Brill Dictionary of Gregory of Nyssa, s. 581-587; Russell, The doctrine of deification, s. 232.

${ }^{24}$ Por. Russell, The doctrine of deification, s. 232.

${ }^{25}$ Por. Szczerba, A Bóg będzie wszystkim we wszystkim, s. 229.

${ }^{26}$ Gregorius Nyssenus, In Ecclesiasten hom. 8, GNO 5, 428.

${ }^{27}$ Por. Balás, Deification, s. 211.

${ }^{28}$ Gregorius Nyssenus, In Ecclesiasten hom. 8, GNO 5, 428, tłum. M. Przyszychowska: Grzegorz z Nyssy, Homilie do Eklezjastesa, ŹMT 51, Kraków 2009, 93.

${ }^{29} \mathrm{GNO} 3 / 1,113$.

${ }^{30}$ Por. Balás, Deification, s. 211. 
cy, która będąc Bogiem z natury posiada moc otwarcia tego, co stworzone, na wspólnotę z tym, co boskie.

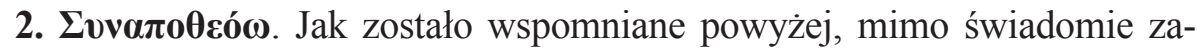
aplikowanej terminologii przebóstwienia na gruncie apofatycznej teologii Autora, zagadnienie to odniesione zostało również wobec procesu osiągającego swą pełnię w Chrystusie. Takie zastosowanie deifikacji nie dotyczy boskiej natury Jezusa, która pozostając $\mathrm{w}$ tajemniczej perychorezie $\mathrm{z}$ człowieczeństwem, jest Boska ze swej istoty. Komentując Grzegorzową koncepcję przebóstwienia wobec Syna Bożego, należy zdecydowanie zaznaczyć zakres owego terminu wyłącznie wobec - w pełni przyjętej przez Jezusa - kondycji ludzkiej. W tym celu Kapadocczyk świadomie ogranicza zastosowanie terminu $\sigma v v \alpha \pi \circ \theta \varepsilon o ́ \omega$, który $\mathrm{w}$ jego dziełach dwukrotnie dotyczy włączenia ludzkiej natury (pleromy) w egzaltację chwały przebóstwionej natury ludzkiej Jezusa dokonującej się w misterium zmartwychwstania, zaś jednokrotnie odnosi się do deifikującego związku pomiędzy sakramentalnym Ciałem Chrystusa a przyjmującym go wiernym ${ }^{31}$ :

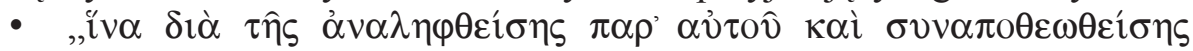

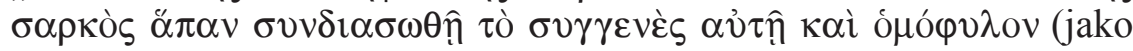
że rzeczywiście zdziałał życie i zarazem ubóstwione, wspólnie zbawia to, co było mu pokrewne i wspólnego pochodzenia)" "32;

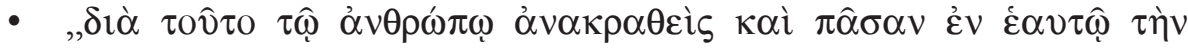

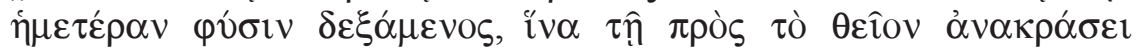

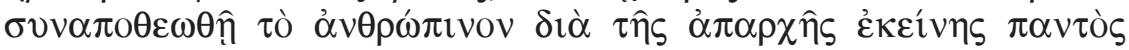

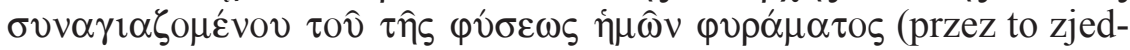
noczył ludzkość przyjąwszy na siebie całą naszą naturę, aby ludzkość została wespółprzebóstwiona w boską jedność, a dzięki tamtym pierwocinom wspólnie uświęcił ciasto naszej natury)"33;

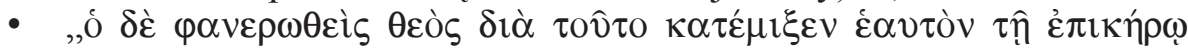

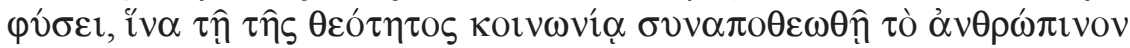
(a objawione Słowo dlatego zmieszało się z podległą zniszczeniu naturą ludzką, aby przez wspólność z boskością ubóstwiło się zarazem człowieczeństwo" ${ }^{34}$.

Ponieważ Biskup Nyssy nigdy nie poświęcił odrębnego traktatu zagadnieniu osoby Syna Bożego, w jego pismach wykład chrystologiczny powiązany został z próbą prezentacji relacji wewnątrztrynitarnych bądź działania Trójcy

${ }^{31}$ Zagadnienie występowania czasownika $\sigma v v \alpha \pi \mathrm{o} \varepsilon \varepsilon \omega_{\omega} \mathrm{w}$ Wielkiej mowie katechetycznej Grzegorza przedstawione zostało w: A. Wyrąbkiewicz, Nauka o przebóstwieniu człowieka w świetle Wielkiej mowy katechetycznej Grzegorza z Nyssy, „Biblica et Patristica Thoruniensia” 6 (2013) 229-238.

${ }^{32}$ Gregorius Nyssenus, Oratio catechetica magna, GNO 3/4, 86, thum. T. Sinko, w: Grzegorz z Nyssy, Wybór pism, Warszawa 1963, 120.

${ }^{33}$ Tenże, Antirrheticus adversus Apollinarium, GNO 3/1, 151, thum. własne.

${ }^{34}$ Tenże, Oratio catechetica magna, GNO 3/4, 97, thum. Sinko, s. 129. 
ad extra ${ }^{35}$. Dlatego też przebóstwienie definitywnie zrealizowane w ludzkiej naturze Chrystusa, które w sposób świadomy Nysseńczyk dwukrotnie określa czasownikiem $\sigma v v \alpha \pi \mathrm{o} \theta \varepsilon \boldsymbol{c}^{36}$, wyrażając współdeifikację człowieka w egzaltacji chwały przy zmartwychwstaniu i wniebowstąpieniu Jezusa ${ }^{37}$, jest wewnętrznie związane z trynitarnym działaniem Boga wobec wszechświata.

Widząc w tajemnicy wcielenia początek dzieła deifikacji człowieka, a przez niego diwinizacji makrokosmosu ${ }^{38}$, Grzegorz wskazuje na ludzką naturę Jezusa jako zaczątek przemiany stworzenia od wewnątrz ${ }^{39}$, która stając

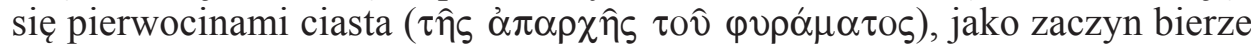

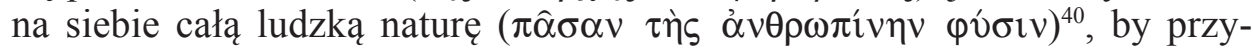
ciągnąć wszystko do tego samego rodzaju ${ }^{41}$, łącząc uświęcenie ludzkości ${ }^{42}$ $\mathrm{z}$ włączeniem pleromy ${ }^{43}$ do jednej monady z Jego w pełni przebóstwionym człowieczeństwem ${ }^{44}$. Na bazie tak pojętej partycypacji ludzkości w uwielbieniu Jezusa, Autor odnosi termin $\sigma v v \alpha \pi \circ \theta \varepsilon ́ \omega$ do deifikacji człowieka, łącząc ją właśnie ze współwyniesieniem dokonującym się w przebóstwionej naturze ludzkiej Syna Bożego ${ }^{45}$. Mówiąc o przebóstwieniu człowieczeństwa Chrystusa, w konsekwencji Nysseńczyk zauważa także, że cała ludzkość jest w jakiś sposób współdeifikowana. Nie dzieje się to na zasadzie deifikacji wszystkich cech albo wszystkich elementów ludzkiej natury, lecz uczestnic-

${ }^{35}$ Głównie w traktacie dogmatycznym: Ad Ablabium quod non sint tres dei, ed. F. Müller, GNO 3/1, 37-57; PG 45, 116-136. Por. B.E. Daley, Divine Transcendence and Human Transformation: Gregory of Nyssa's Anti-Apollinarian Christology, StPatr 32/4 (1997) 88.

${ }^{36}$ Gregorius Nyssenus, Oratio catechetica magna, GNO 3/4, 86; tenże, Antirrheticus adversus Apollinarium, GNO 3/1, 151.

${ }^{37}$ Por. Balás, Deification, s. 212.

${ }^{38}$ Szerzej na ten temat zob. Kotkowska, Pomyśleć świat jako całość.

${ }^{39}$ Por. taż, Nauczanie św. Grzegorza z Nyssy o wszechmocy Bożej na podstawie In illud: Tunc ipse Filius, VoxP 24 (2004) t. 46-47, 521.

${ }^{40}$ Gregorius Nyssenus, In Canticum canticorum hom. 14, ed. H. Langerbeck, GNO 6, Leiden 1960, 427-428.

${ }^{41}$ Por. tenże, De perfectione Christiana ad Olympium monachum 71, ed. W. Jaeger, GNO 8/1, 205, tłum. J. Naumowicz, w: Grzegorz z Nyssy, O naśladowaniu Boga. Pisma ascetyczne, BOK 15, Kraków 2001, 82.

${ }^{42}$ Por. Gregorius Nyssenus, In Canticum canticorum hom. 14, GNO 6, 381.

${ }^{43}$ Termin pleroma (pełnia) w odniesieniu do ludzkości oznacza określoną liczbę istnień należących do wspólnej natury, utworzonej przy pierwszym acielesnym i aczasowym stworzeniu jako niepodzielna monada, która nie może się pomnażać. Choć Grzegorz stosuje termin pleroma w wielorakim kontekście, m.in. dla wyrażenia pełni Bóstwa czy wspólnej natury Boga, w niniejszym artykule używany będzie on wyłącznie na określenie całościowo pojętej monady ludzkiej. Por. M. Przyszychowska, w: Grzegorz z Nyssy, O stworzeniu człowieka, ŹMT 39, Kraków 2006, 98, nota 74; taż, Koncepcja podwójnego stworzenia jako próba wyjaśnienia genezy świata zmystowego (Filon z Aleksandrii, Orygenes, Grzegorz z Nyssy), VoxP 23 (2003) t. 44-45, 214-215; Szczerba, A Bóg będzie wszystkim we wszystkim, s. 259.

${ }^{44}$ Por. Gregorius Nyssenus, De perfectione Christiana ad Olympium monachum 69, GNO 8/1, 204, BOK 15, 81.

${ }^{45}$ Por. tenże, Oratio catechetica magna, GNO 3/4, 86. 
twa jednostek we wspólnej naturze ludzkiej ${ }^{46}$. Ograniczając się do krótkich stwierdzeń ${ }^{47}$ Grzegorz nie kreśli dokładnego schematu perychorezy pleromy z misterium przebóstwienia natury ludzkiej Syna Bożego, jednak z głębokim przekonaniem podkreśla istniejącą pomiędzy nimi łączność, jako przyczynę warunkującą deifikację człowieka. Perychoreza ta stanowi więc obszar obiektywnej, dokonanej w Jezusie, deifikacji, która staje się ofertą dla ludzkości do podjęcia przebóstwienia subiektywnego. Stąd misterium wcielenia i zmartwychwstania otwierają przed indywidualnym człowiekiem potencjalne współprzebóstwienie, aż do przebóstwienia wszystkich jednostek pleromy na drodze współpracy z łaską. Inicjacja procesu deifikacji zostanie więc przez Kapadocczyka ściśle powiązana z sakramentem chrztu, jako misterium in-

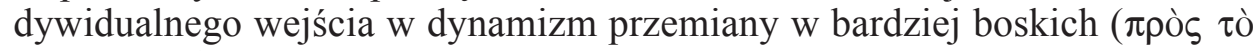
$\theta \varepsilon \imath$ ć $\varepsilon \rho \nu)^{48}$.

Progres drogi przebóstwienia w sakramentalnym życiu Kościoła, do którego odnosi się trzecie zastosowanie terminu $\sigma v v \alpha \pi \circ \theta \varepsilon \cos ^{49}$, pogłębia się w doktrynie Nysseńczyka wraz z sakramentalnym przyjmowaniem Ciała Pańskiego $^{50}$. I choć Eucharystia odgrywa ważną rolę u wszystkich trzech Kapadocczyków, tylko Biskup Nyssy rozważa ją w kontekście deifikacji, ujmując jej działanie analogicznie do misterium wcielenia: Bóg przebóstwia ciało we wcieleniu dzięki zmieszaniu się z tym, co ludzkie, zaś Ciało Chrystusa deifikuje wierzących przez zmieszanie się z nimi w komunii eucharystycznej ${ }^{51}$. W niej bowiem ciało, które przyjęło Boga ( $\tau$ ò $\theta \varepsilon o \delta o ́ \chi o v ~ \sigma \hat{\omega} \mu \alpha)$ jednoczy się w intymnej relacji z Bóstwem ${ }^{52}$ oraz oczyszcza się z nieczystości ${ }^{53}$, aby „dusza mogła zostać wprowadzona w stan uniesienia ku Bożym rzeczywistościom

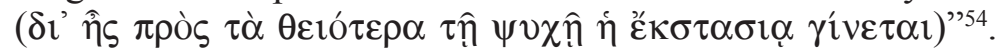

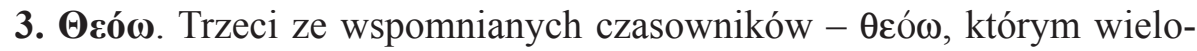
krotnie posługiwał się Grzegorz z Nazjanzu, w całym dorobku Nysseńczyka występuje tylko jeden raz - w De beneficentia ${ }^{55}$. Wówczas Autor używa go

${ }^{46}$ Por. Balás, Deification, s. 212.

${ }^{47}$ Por. Gregorius Nyssenus, Oratio catechetica magna, GNO 3/4, 86; tenże, Antirrheticus adversvs Apollinarium, GNO 3/1, 151.

${ }^{48}$ Tenże, In Canticum canticorum hom. 1, GNO 6, 14-15.

49 Tenże, Oratio catechetica magna, GNO 3/4, 97.

${ }^{50}$ Nysseńczyk dzięki ujęciu sakramentu Eucharystii w kontekście deifikacji prezentuje realistyczną teorię transsubstancjacji według własnej wykładni mistycznej, a także nawiązuje do szkoły aleksandryjskiej, podkreślającej realizm i spirytualizm obecności Boga pod fizyczną postacią eucharystyczną. Por. Rother, Gottverähnlichung, s. 528; Strękowski, Sofiologia św. Grzegorza, s. 202-203.

${ }^{51}$ Por. Russell, The doctrine of deification, s. 233.

52 Por. Gregorius Nyssenus, Oratio catechetica magna, GNO 3/4, 97, tłum. Sinko, s. 128.

${ }^{53}$ Por. tenże, In Canticum canticorum hom. 10, GNO 6, 310.

${ }^{54}$ Tamże, tłum. M. Przyszychowska, ŹTM 43, Kraków 2007, 164.

${ }^{55}$ GNO 9, 103. 
nawiązując do cnót litości i wspaniałomyślności, które będąc świętymi atrybutami, deifikują człowieka, w którym się znajdują ${ }^{56}$ :

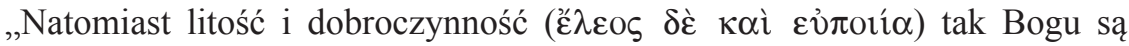
miłe, jak i Boskim czynią człowieka ( $\theta \varepsilon \circ \hat{\sigma} \sigma \mathrm{v} \alpha$ ờòv), w którym zamiesz-

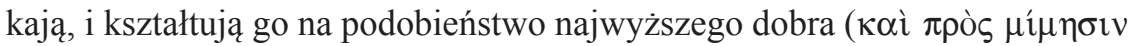

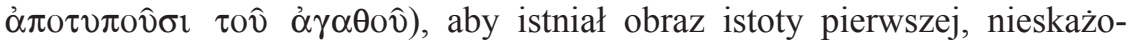

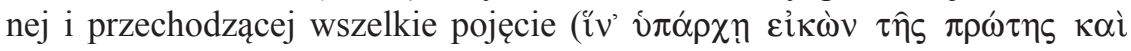

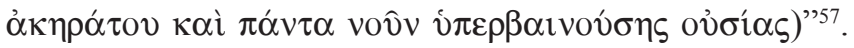

Ponownie więc Nysseńczyk poszerza katalog środków deifikujących człowieka ze względu na pierwszorzędne źródło wskazanych cnót, którym jest

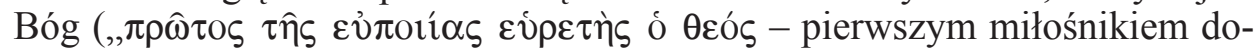

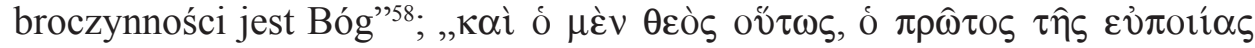

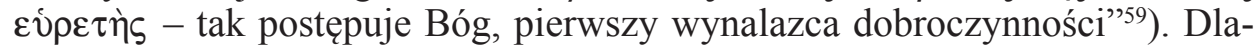
tego też Kapadocczyk w traktacie De opificio hominis twierdzi, że cnoty złożone w naturze ludzkiej przez Stwórcę, tworzące w niej katalizator rozwoju ku realizacji „obrazu Bożego”, na wzór którego powstał człowiek (por. Rdz 1, 26), są nie tyle cechami ofiarowanymi ludzkości, lecz cnotami, którymi Bóg się podzielił ${ }^{60}$. Myśl ta wiąże wewnętrznie ideę deifikacji z partycypacją

${ }^{56}$ Por. Balás, Deification, s. 211.

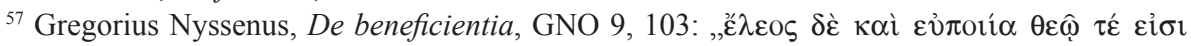

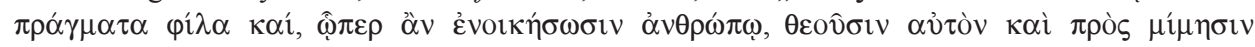

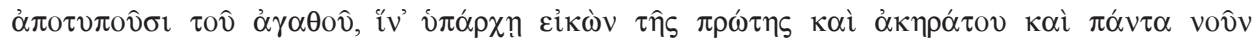

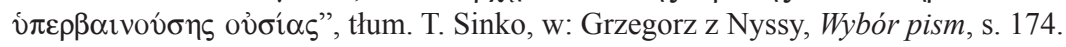

${ }^{58}$ Tenże, De beneficientia, GNO 9, 101, thum. Sinko, s. 172.

${ }^{59}$ Tamże, GNO 9, 102, thum. Sinko, s. 173.

${ }^{60}$ Por. tenże, De opificio hominis, ed. H. Hörner, Supplement to the GNO series, Leiden 1972 ,

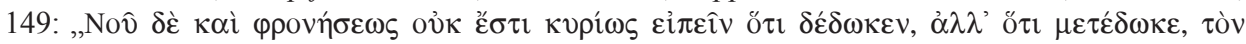

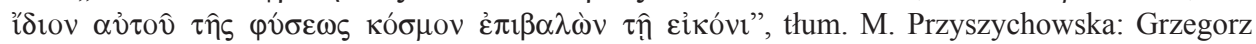
z Nyssy, O stworzeniu człowieka, ŹMT 39, 69: „Nie można jednak w sposób właściwy powiedzieć o umyśle (vov̂s) i mądrości ( $\varphi \rho o ́ v \eta \sigma ı \varsigma)$, że nam je ofiarował, ale raczej, że dał nam w nich udział, ozdabiając obraz właściwością swojej własnej natury". Wśród całego szeregu atrybutów złożonych w naturze ludzkiej Grzegorz, jak zaznacza J. Gross (La divinisation du chrétien d'après les Pères Grecs. Contribution historique a la doctrine de la grâce, Paris 1938, 223-224), za najważniejsze uznaje rozum i wolną wolę, które tworzą w ludzkości trwałe podobieństwo, czym Autor wpisuje się w powszechną ideę Aleksandryjczyków, akcentujących podobieństwo człowieka do Boga dzięki umysłowi. Te zasadnicze środki kształtują jednak w człowieku rozwój cnót, które również z nadania Bożego złożone zostały w pleromie jako środki deifikujące. Cnoty wraz z wolnością i rozumnością, łącznie stanowią barwy, jakimi człowiek odmalować winien w sobie własny Pierwowzór - Obraz Boży, przy jednoczesnym zastrzeżeniu, że narzędzia te nigdy nie należą do człowieka, lecz są mu pozostawione do dyspozycji na zasadzie udziału w cechach Boskich, bez których niemożliwa byłaby realizacja ikonicznego powołania człowieka. Por. W. Völker, Gregorio di Nissa, filosofo e mistico, tr. C. Tommasi, Milano 1993, 73; E. Kotkowska, Teologia łaski i wolności w nauczaniu świętego Grzegorza z Nyssy, TPatr 3 (2006) 143-160. Szerzej na temat obrazu Bożego złożonego w naturze ludzkiej u Nysseńczyka zob. L.F. MateoSeco, Obrazy obrazu (Rodzaju 1, 26 i Kolosan 1, 15 uśw. Grzegorza z Nyssy), VoxP 26 (2006) t. 49, 367-382. 
w naturze Boskiej, ponieważ według Nysseńczyka człowiek nabiera atrybutów przynależących absolutnie i właściwie tylko Bogu, sam zaś posiada je o tyle, o ile otrzymuje udział w swym Stwórcy, stąd według Grzegorzowej antropologii godność bycia obrazem wypełnia się dzięki uczestnictwu w samym Oryginale ${ }^{61}$.

\section{DYNAMIKA PRZEBÓSTWIENIA W CHARAKTERYSTYCZNYCH ZWROTACH}

Chcąc wyrazić sedno procesu przebóstwienia człowieka, Kapadocczyk znacznie częściej odwoływał się do pojęć opisowych, oddających związek zachodzący między Bogiem a człowiekiem w kategoriach relacyjności (ad-

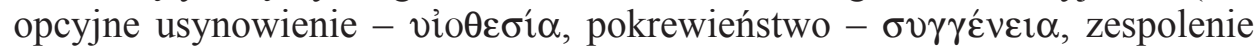

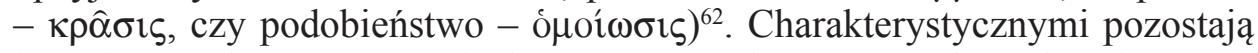
jednak specyficzne wyrażenia, które w pismach Nysseńczyka wskazują na dynamikę i realność zachodzącej w człowieku zmiany, m.in.:

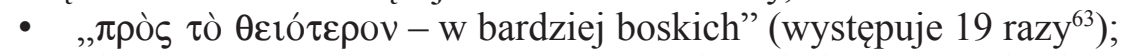

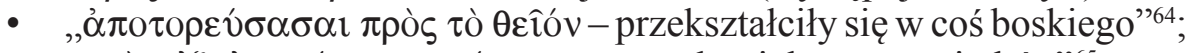

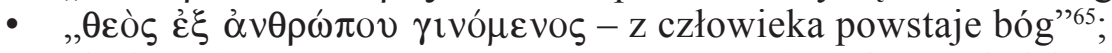

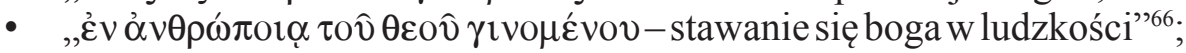

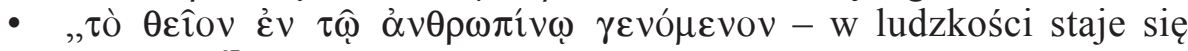
boskość" ${ }^{\circ 7}$;

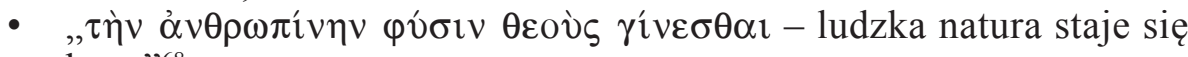
bożą" ${ }^{68}$;

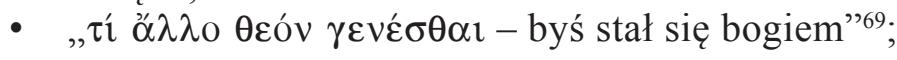

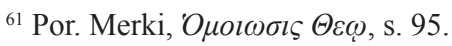

${ }^{62}$ Por. Strękowski, Sofiologia św. Grzegorza, s. 188; Rother, Gottverähnlichung, s. 513; C. Schönborn, Przebóstwienie, życie i śmierć, thum. W. Szymona, Poznań 2001, 44; Żelazny, Patrystyczna doktryna o powołaniu człowieka, s. 73; Špidlik - Gargano - Grossi, Duchowość Ojców Kościoła, s. 47.

${ }^{63}$ Gregorius Nyssenus, Antirrheticus adversus Apollinarium, GNO 3/1, 228; tenże, De mortuis, ed. G. Heil, GNO 9, 59, 64 i 65; tenże, Oratio consolatoria in Pulcheriam, ed. A. Spira, GNO 9, 467; tenże, De perfectione christiana ad Olympium monachum, GNO 8/1, 213; tenże, In sextum Psalmum, ed. J. McDonough, GNO 5, 188; tenże, In Canticum canticorum hom. 1, GNO 6, 15 i 29; tamże 5, GNO 6, 156; tamże 8, GNO 6, 253; tamże 9, GNO 6, 262; tamże 11, GNO 6, 334; tamże 15, GNO 6, 431; tenże, Epistula 3, 16, ed. G. Pasquali, GNO 8/2, Leiden 1959, 24; tenże, De vita Moysis II 321, ed. J. Daniélou, SCh 1, Paris $1968^{3}$, 326; tenże, De oratione dominica or. 5, ed. J.F. Callahan, GNO 7/2, 292; tenże, In Basilium fratrem 7, ed. O. Lendle, GNO 10/1, Leiden 1990, 115; tenże, In illud: Tunc et ipse filius, ed. J.K. Downing, GNO 3/2, Leiden 1987, 18.

${ }^{64}$ Tenże, In Canticum canticorum hom. 14, GNO 6, 410.

${ }^{65}$ Tenże, De beatitudinibus or. 7, GNO 7/2, 151. Zob. tamże, GNO 7/2, 124-125: „Өعóv $\gamma \varepsilon v \varepsilon ́ \sigma \theta \alpha \imath "$

${ }^{66}$ Tenże, Antirrheticus adversus Apollinarium, GNO 3/1, 202.

${ }^{67}$ Tenże, Ad Theophilum adversus Apollinaristas, ed. F. Müller, GNO 3/1, 124.

${ }^{68}$ Tenże, De oratione dominica or. 5, GNO 7/2, 292.

${ }^{69}$ Tenże, De beatitudinibus or. 5, GNO 7/2, 124. 
-,$\mu о \rho \varphi \omega \theta \varepsilon \dot{\varepsilon} \tau \alpha \alpha \hat{\omega} \tau \hat{\eta} \varsigma$ $\theta \varepsilon o ́ \tau \eta \tau o \varsigma ~ i \delta i \omega ́ \mu \alpha \tau \imath-$ ukształtowany na wzór cechy boskiej"70;

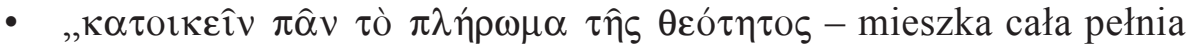
Bóstwa" (występuje 4 razy $^{71}$ ).

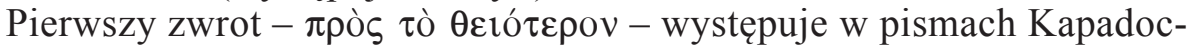
kiego Autora z niezwykle dużą częstotliwością i pojawia się we wszystkich rodzajach dzieł ${ }^{72}$, głównie jednak w egzegetycznym komentarzu In Canticum canticorum, w którym Grzegorz, już od pierwszych stron zaznacza, że ci, którzy zostali przyodziani szatą Jezusa Chrystusa przemienili się ,,w niepodlega-

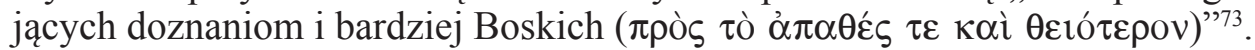
W wyrażeniach tych dynamika progresu deifikacji zostaje przez Nysseńczyka podkreślona dzięki zestawionym czasownikom: $\sigma v \mu \mu \varepsilon \tau \alpha \mu о \rho \varphi o ́ \omega^{74}$ (wspólnie zmieniać, przemieniać) ${ }^{75}, \mu \varepsilon \tau \alpha \pi$ oté $\omega^{76}$ (przerabiać, na nowo układać, prze-

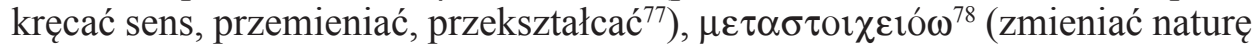
czegoś, zmienić w inny żywioł, zmienić się ${ }^{79}$ ), czy $\mu \varepsilon \tau \alpha \sigma \kappa \varepsilon v \alpha ́ \zeta \omega^{80}$ (przebrać się, przebudować, poprawić, ulepszyć, przekształcić $\left.{ }^{81}\right)$. Dzięki takiemu zabie-

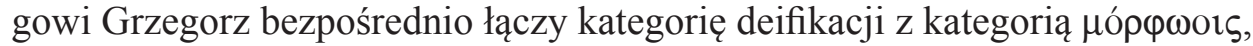
kształtowania człowieka na obraz Boga, odpowiadającej także Arystotelesowskiej $\dot{\varepsilon} v \tau \varepsilon \lambda \dot{\varepsilon} \chi \imath \alpha$ - formie określającej kierunek rozwoju pojedynczego człowieka i całej ludzkości ${ }^{82}$. Forma ta, akcentowana przez Autora w ikonicznym charakterze pleromy (Rdz 1, 26), stanowi właściwe naśladownictwo Boskiej natury $^{83}$ - podstawowy wymiar życia chrześcijańskiego obszernie komento-

70 Tamże.

${ }^{71}$ Tenże, Antirrheticus adversus Apollinarium, GNO 3/1, 173; tenże, De vita Moysis II 177 , SCh 1, 183; tenże, Ad imaginem dei et ad similtudinem, PG 44, 1336; tenże, Ad Eustahium de Sancta Trinitate, ed. F. Müller, GNO 3/1, 7.

${ }^{72}$ Podział dzieł Grzegorza za: S. Lilla, Introduzione, w: Gregorio di Nissa - Giovanni Crisostomo, La verginità, Roma 1990, 13-16.

${ }^{73}$ Gregorius Nyssenus, In Canticum canticorum hom. 1, GNO 6, 15, thum. M. Przyszychowska: Grzegorz z Nyssy, Homilie do Pieśni nad pieśniami, ŹMT 43, Kraków 2007, 23.

74 Tamże, GNO 6, 15 i 253-254.

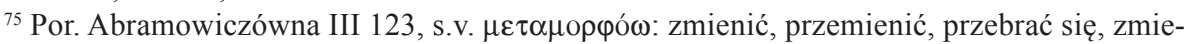
nić wygląd.

${ }^{76}$ Gregorius Nyssenus, Antirrheticus adversus Apollinarium, GNO 3/1, 228; tenże, De perfectione christiana ad Olympium monachum, GNO 8/1, 213; tenże, In Canticum canticorum hom. 8, GNO 6, 29, 253, 262 i 431; tenże, Epistula 3, 16, GNO 8/2, 24.

77 Por. Abramowiczówna III 125-126, s.v. $\mu \varepsilon \tau \alpha \pi$ oté $\omega$.

${ }^{78}$ Gregorius Nyssenus, De mortuis, GNO 9, 59; tenże, In sextum Psalmum, GNO 5, 188. W for-

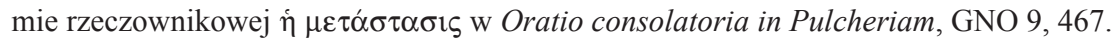

${ }^{79}$ Por. Abramowiczówna III 128, s.v. $\mu \varepsilon \tau \alpha \sigma \tau o \imath \chi \varepsilon \imath o ́ \omega$.

${ }^{80}$ Gregorius Nyssenus, De mortuis, GNO 9, 64; In Basilium fratrem 7, GNO 10/1, 115.

${ }^{81}$ Por. Abramowiczówna III 127, s.v. $\mu \varepsilon \tau \alpha \sigma \kappa \varepsilon v \alpha ́ \zeta \omega$.

${ }^{82}$ Por. T. Grodecki, Dlaczego wszyscy musza być zbawieni? Zbawienie i Kościół u Grzegorza z Nyssy, SACh 17 (2004) 111.

${ }^{83}$ Por. Gregorius Nyssenus, De perfectione christiana ad Olympium monachum, GNO 8/1, 213. 
wany przez Nysseńczyka w De perfectione christiana ad Olympium monachum czy De professione christiana ad Harmonium. Kategoria ta w De beatitudinibus skupi się wokół kształtowania człowieka na wzór cechy właściwej

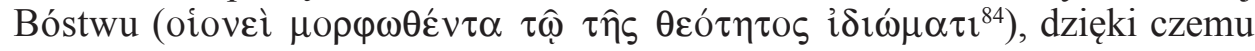
Autor uwydatni błogosławieństwa, bądź konkretne cnoty z nimi powiązane, m.in. miłosierdzie, jako cechy będące właściwościami Boga, w których i człowiek może mieć uczestnictwo, jednocześnie poddając się ich deifikującemu działaniu ${ }^{85}$.

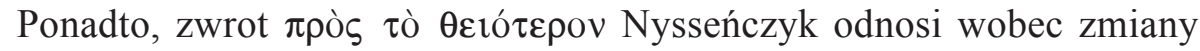

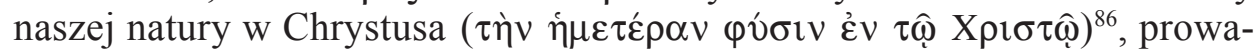
dzącej w konsekwencji do „objawienia się w nas prawdziwego życia ( $\alpha$ $v \alpha-$

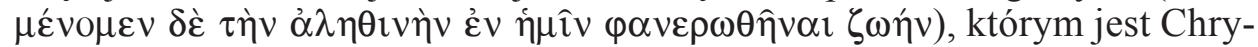

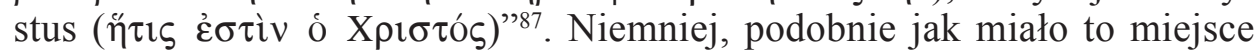
w przypadku czasowników, Grzegorz podając skutki owego przeobrażenia, najczęściej nie określa samego schematu dokonania się w człowieku procesu

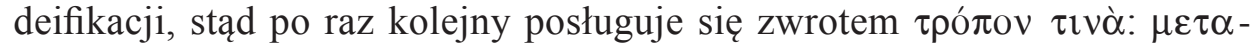

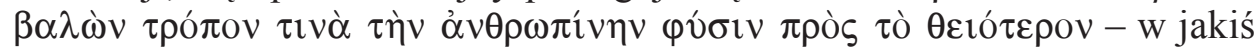
sposób naturę ludzką zmieniając w bardziej boską ${ }^{88}$. Fragment, w którym Autor najobszerniej doprecyzuje dokonujące się w człowieku misterium, stanowi komentarz do zrównania natury ludzkiej z bytami niecielesnymi, a więc osiągnięcia jednego z głównych skutków deifikacji - niepodatności na doznania ( $\tau$ ò $\alpha \pi \alpha \theta \grave{\varepsilon} \varsigma)$ :

„Głos Słowa zawsze jest pełen mocy, więc jak przy pierwszym stworzeniu zajaśniało światło na Jego rozkaz i na Jego słowo powstał firmament oraz całe pozostałe stworzenie pojawiło się równocześnie ze stwórczym słowem, tak samo, gdy teraz Słowo zachęciło Oblubienicę, która stała się lepsza, by szła $\mathrm{ku}$ Niemu, ta natychmiast razem z rozkazem otrzymała stosowne siły i stała się taka, jak chciał Oblubieniec; przemieniona w bardziej Boską $(\mu \varepsilon \tau \alpha-$

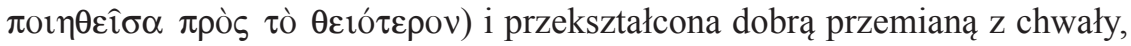

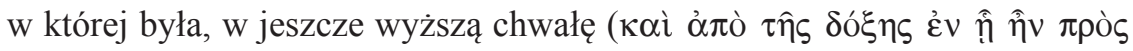

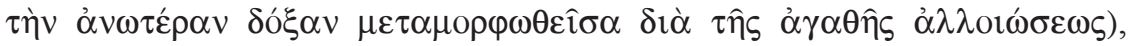
stała się przedmiotem podziwu dla chóru aniołów otaczającego oblubieńca, i wszyscy kierują do niej przychylnie pełne podziwu słońca: «Umocniłaś nam serce, nasza siostro, oblubienico». Znak niepodatności na doznania (ó $\tau \hat{\eta} \varsigma$

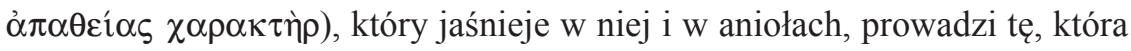
w ciele stała się niepłodna na doznania ( $\tau$ ò $\alpha \pi \alpha \theta \dot{\varepsilon} \varsigma$ ), do pokrewieństwa i braterstwa z bytami niecielesnymi" ${ }^{\prime 9}$.

\footnotetext{
${ }^{84}$ Tenże, De beatitudinibus or. 5, GNO 7/2, 124-125.

${ }^{85}$ Por. tamże.

${ }^{86}$ Tenże, Epistula 3, 16, GNO 8/2, 24.

${ }^{87}$ Tenże, In Canticum canticorum hom. 9, GNO 6, 262, ŹMT 43, 143.

${ }^{88}$ Tenże, De oratione dominica or. 5, GNO 7/2, 290, 292.

${ }^{89}$ Tenże, In Canticum canticorum hom. 8, GNO 6, 253-254, ŹMT 43, 137-138.
} 
Chcąc jeszcze dobitniej podkreślić ideał apathei w deifikacji, Nysseńczyk

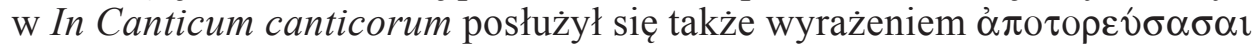

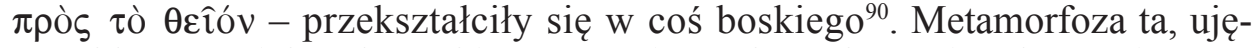
ta w kluczu stoicko-platońskim, stanowić ma konsekwencję odrzucenia tego, co cielesne i zbędne, by porzuciwszy wszelkie materialne przyzwyczajenie wznieść się ku temu, co duchowe.

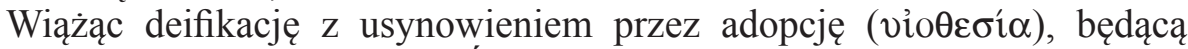
szczególnym działaniem Ducha Świętego ${ }^{91}$, Grzegorz metaforycznie wskazuje na zaistniałą zmianę statusu przebóstwianego poprzez użycie w dziele $D e$

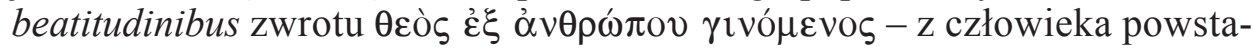
je bóg. Analogia ta stanowi splot prawdy o istniejącym między Bogiem

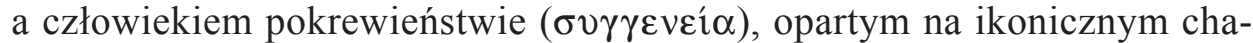
rakterze pleromy (por. $\operatorname{Rdz} 1,26$ ) oraz powiązaniu synostwa z przekazywaniem chwały Ojca, która - w odróżnieniu od jedynego synostwa Jezusa Chrystusa - pozostaje zaszczytem związanym z wywyższeniem człowieka do godności syna Bożego dzięki łasce:

„Z tak wielką rzeczywistością, której ani zobaczyć, ani usłyszeć, ani objąć rozumem nie można, człowiek, który między bytami poczytany jest za nic, który jest pyłem, trawą i marnością, jednoczy się, gdy Bóg wszechrzeczy bierze

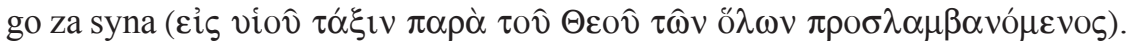
[...]. Człowiek wymyka się swojej własnej naturze, ze śmiertelnego stając się nieśmiertelnym, z upadłego czystym, z przemijającego wiecznym, jed-

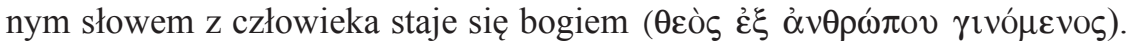

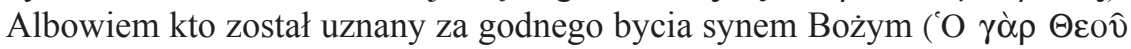

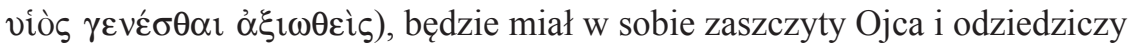
wszystkie Ojcowskie dobra. O, jak wielka jest hojność bogatego Pana, wielka miara, szczodra ręka, jak ogromne dary nieprzebranych skarbów! Z miłości do ludzi podniósł zeszpeconą grzechem naturę do poziomu swojej chwały

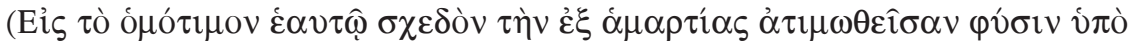
$\varphi \imath \lambda \alpha v \theta \rho \omega \pi i \alpha \varsigma$ $\alpha$ $\gamma \varepsilon \imath)$. Jeśli bowiem udzielił ludziom podobieństwa do tego, czym On sam jest z natury, cóż innego obiecał przez pokrewieństwo ( $\delta i \grave{\alpha} \tau \hat{\eta} \varsigma$

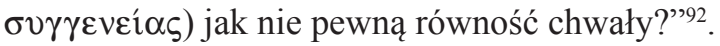

Zdecydowanie jednak Grzegorz przestrzega przed skrajnym rozumieniem idei przebóstwienia człowieka, co w precyzyjny sposób wyjaśnia w dziele Antirrheticus adversvs Apollinarium ${ }^{93}$ posługując się kolejnym charaktery-

\footnotetext{
${ }^{90}$ Por. Gregorius Nyssenus, In Canticum canticorum hom. 14, GNO 6, 410.

${ }^{91}$ Por. L. Turcesu, ,Blessed Are the Peacemakers, for They Will Be Called Sons of God” (Mt 5, 4). Does Gregory of Nyssa Have a Theology of Adoption?, w: Gregory of Nyssa, Homilies on the Beatitudes, s. 399.

${ }^{92}$ Gregorius Nyssenus, De beatitudinibus or. 7, GNO 7/2, 151, thum. M. Przyszychowska: Grzegorz z Nyssy, Homilie do błogosławieństw, ŹMT 34, Kraków 2005, 86.

${ }^{93}$ GNO 3/1, 202.
} 


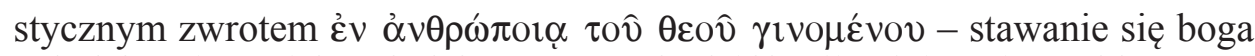
w ludzkości. Nacisk na kolektywny aspekt deifikacji pełni tu niezwykle ważną funkcję, ponieważ dzięki niemu Nysseńczyk ostrzega przed pokusą wielobóstwa, wiążącą się z dosłownie przyjętą zmianą natury człowieka w bóstwo, tak, jakby w ludzkość wprowadzonych miało zostać mnóstwo bogów ( $\pi \lambda \hat{\eta} \theta$ os

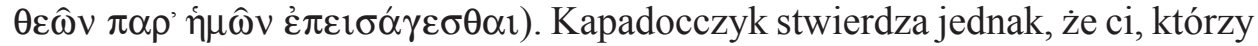

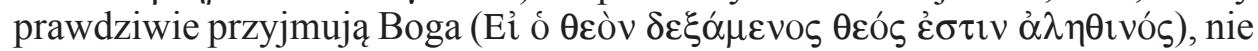

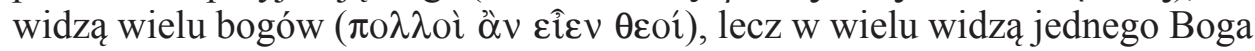

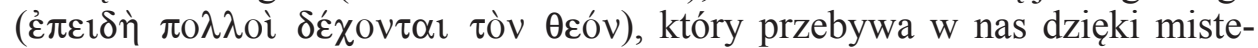
rium Jezusa. Stąd owa kolektywność staje się właściwym obszarem deifikacji człowieka wyznającego w Chrystusie Boga, który stanowi przyczynę i wzór stawania się Boga w ludzkości (

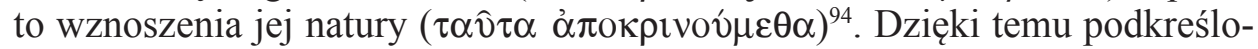
na została różnica między niedostępną ov̉oí $\alpha$ Boga, który stanowi cel drogi przebóstwienia, od ov̉ $\sigma^{\prime} \alpha$ poddanego owej drodze człowieka, który bogiem w istocie nigdy się nie stanie. Sednem procesu deifikacji według Grzegorza jest więc chrystocentryzm, umożliwiający dokonujące się w całej ludzkości pojednanie i zjednoczenie z Bogiem, a samą naturę ludzką czyni teoforyczną $(\theta \varepsilon о \varphi o ́ \rho \omega ~ \alpha ̉ v \theta \rho \omega ́ \pi \omega)^{95}$, ponieważ ,pokrewnieństwo z Bogiem jest udziałem

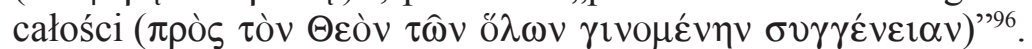

Mistyczny wymiar deifikacji zostaje silnie uwydatniony przez Biskupa Nyssy w piątej homilii De oratione dominica dzięki szeregowi wyrażeń oddających deifikację jako upodobnienie się do Boga przez cnotę ( $\tau \hat{\omega} \theta \varepsilon \hat{\omega} \hat{\omega} \delta i \grave{\alpha} \tau \hat{\eta} \varsigma$

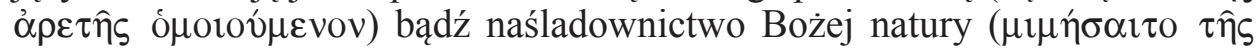

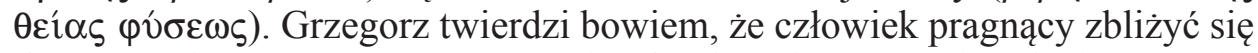

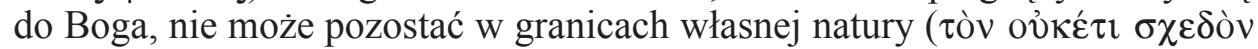

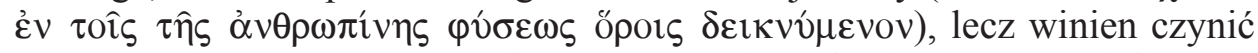

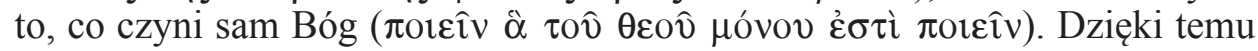
Nysseńczyk jasno wskazuje na czynny udział człowieka w deifikacji, który „W pewnym znaczeniu staje się Bogiem, dowodząc, że się do Niego upodab-

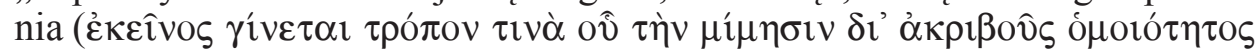
$\dot{\varepsilon} \pi \varepsilon \delta \varepsilon \dot{\xi} \xi \alpha \tau)$ "'97. Stąd, jak zauważa Hans Urs von Balthasar, to właśnie na zasadzie nieustannego przekraczania siebie, pokonywania wyznaczonych granic

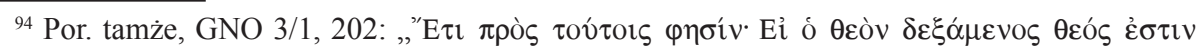

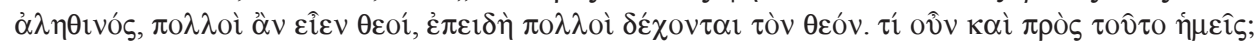

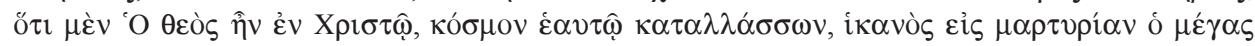

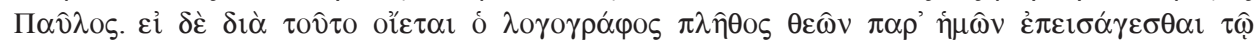

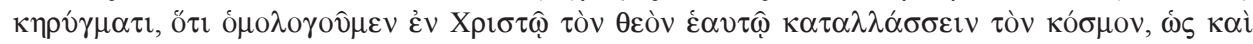

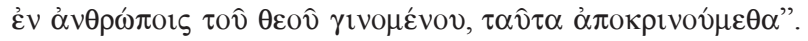

${ }^{95}$ Por. tamże.

${ }^{96}$ Tenże, De beatitudinibus or. 1, GNO 7/2, 78, ŹMT 34, 31.

${ }^{97}$ Tenże, De oratione dominica or. 5, GNO 7/2, 290, thum. W. Kania, w: Modlitwa Pańska. Komentarze greckich Ojców Kościoła IV-Vw., red. K. Bielawski, Kraków 2004, 78. 
własnej natury w logice $\dot{\varepsilon} \pi \dot{\varepsilon} \kappa \tau \alpha \sigma ı \varsigma^{98}$ skupia się cała mistyka zaprezentowana w duchowych pismach Autora, bazująca na tendencji wzrostowej aż do wybuchu boskości z samej jednostki ${ }^{99}$. Proces ten, niemożliwy do osiągnięcia bez działania przyczyny sprawczej deifikacji, którą jest Bóg, co też wskazuje na kluczową rolę współpracy między działaniem Boga a działaniem człowieka $(\sigma v \vee \varepsilon ́ \rho \gamma \varepsilon \imath \alpha)^{100}$, pozostaje tajemnicą, którą w nieco dalszym fragmencie De oratione dominica Grzegorz podkreśli dwukrotnie posługując się wspomnia-

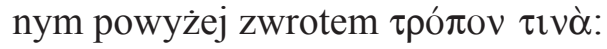

„Kto odrzucił wszystko złe od siebie, ten przez tego rodzaju duchowe wyro-

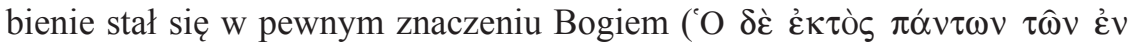

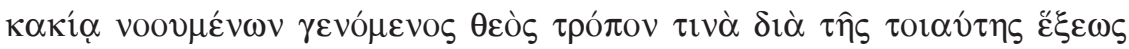

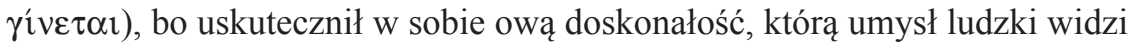

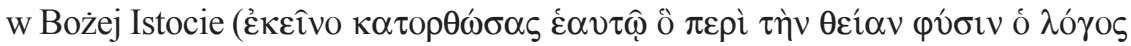
$\beta \lambda \varepsilon ́ \pi \varepsilon \imath)$. Zdajesz sobie więc sprawę, jak przez słowa modlitwy podnosi Pan wszystkich, którzy Go słuchają, i jak ludzką naturę przemienia na Bożą $(\mu \varepsilon-$

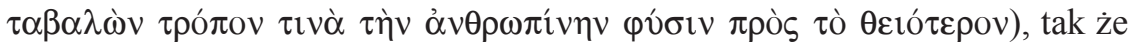

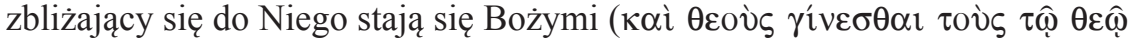

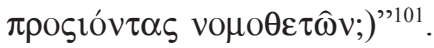

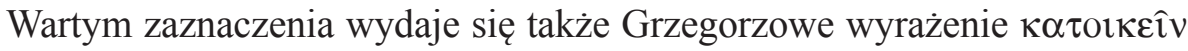

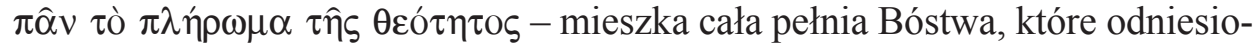
ne zostało do tajemnicy Logosu bądź Jego ciała, jako przybytku boskości ${ }^{102}$. Niemniej zwrot ten, ukazuje także powiązanie tajemniczego współprzebywania Boga z człowiekiem, które realizuje się poprzez zamieszkanie w Nim, jako Przybytku pełnym boskości. Związek ten jest zauważalny m.in. w In inscrip-

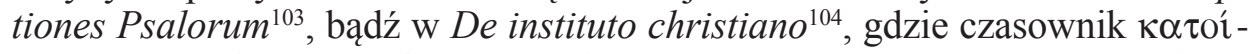

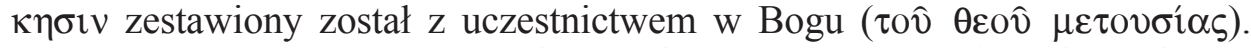
Grzegorz opisuje w nim zamieszkanie Chrystusa w sercu człowieka, dokonujące się dzięki wierze i mocy Ducha Świętego. Natomiast w In Canticum can-

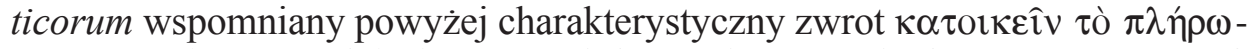

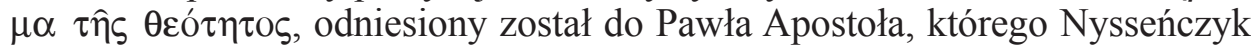
przedstawia jako przykład człowieka przebóstwionego, nawiązując do wyznania Apostoła z Ga 2, 20: „Teraz już nie ja żyje, lecz żyje we mnie Chrystus”105, czym po raz kolejny Kapadocczyk podkreśla chrystocentryzm deifikacji.

\footnotetext{
${ }^{98}$ Por. Daniélou, Platonisme et théologie mistique, s. 309.

${ }^{99}$ Por. H.U. von Balthasar, Presence and Thought. An Essay on the Religious Philosophy of Gregory of Nyssa, transl. M. Sebanc, San Francisco 1995, 38.

${ }^{100}$ Por. Strękowski, Sofiologia św. Grzegorza, s. 157; Żelazny, Patrystyczna doktryna o powotaniu człowieka, s. 59.

${ }^{101}$ Gregorius Nyssenus, De oratione dominica or. 5, GNO 7/2, 292, thum. Kania, s. 79.

${ }^{102}$ Por. tenże, De vita Moysis 2, 177, SCh 1, 249.

${ }^{103}$ Ed. J. McDonough, GNO 5, 36.

${ }^{104}$ Ed. W. Jaeger, GNO 8/1, 59.

${ }^{105}$ Tenże, In Canticum canticorum hom. 15, GNO 6, 440-441.
} 


\section{ZALEŻNOŚĆ MIĘDZY TERMINOLOGIĄ PRZEBÓSTWIENIA I PARTYCYPACJI}

Zachowując ortodoksyjny charakter własnej nauki Grzegorz przeplata $\mathrm{w}$ swoich pismach terminologię przebóstwienia i partycypacji w Bogu ${ }^{106}$

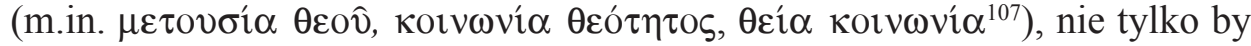
podkreślić ciągłość duchowego procesu, która w ontycznym wymiarze $\mu \varepsilon$ -

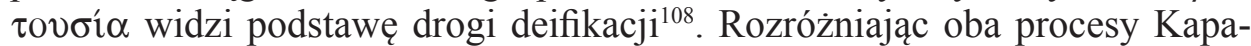
docczyk, jak zaznaczają niektórzy badacze (m.in. Norman Russell ${ }^{109}$ ), unika bezpośredniego stosowania terminologii uczestnictwa do opisu przebóstwienia człowieka, by nie dopuścić do naruszenia jakiejkolwiek transcendencji niestworzonego Boga. Czyniąc wyraźne rozgraniczenie językowe Ojciec Kapadocki przeciwstawia się idei zastanej w platonizmie, głoszącej możliwość uczestnictwa w samej istocie Bóstwa, i zdecydowanie podkreśla myśl o udziale przez uczestnictwo uwarunkowane łaską ${ }^{110}$. Opierając się na wschodniej doktrynie o unii energetycznej z Bogiem, Grzegorz w swoich najbardziej dojrzałych dziełach wolał częściej mówić o procesie partycypacji, aby wystrzec się czegokolwiek, co mogłoby choćby przejawiać tendencję do naruszenia istoty Boga. Stąd też Nysseńczyk tak dużą uwagę przykładał do świadomego i wyraźnego wykorzystania terminologii przebóstwienia, zaś użycie języka udziału w boskości, Bogu lub naturze Boskiej ${ }^{111}$ dostarczyło mu alternatywy dla zachowania apofatycznego pojęcia Boga.

Powyższa prezentacja podstawowych narzędzi językowych oraz charakterystycznych zwrotów służących w pismach Kapadockiego Autora do wyrażenia idei przebóstwienia, jak i rozgraniczenie bliskich sobie zakresów znaczeniowych terminologii deifikacji i partycypacji, wskazuje, że język przebóstwienia spotykany w pismach Grzegorza zastosowany został w zróż-

${ }^{106}$ Język uczestnictwa, partycypacji w Bogu przenika przede wszystkim trzy dzieła Grzegorza: De vita Moysis, In Canticum canticorum oraz De beatitudinibus; por. Ludlow, Divine infinity and eschatology, s. 234.

${ }^{107}$ Według J. Rothera (Gottverähnlichung, s. 563), łączącego w pismach Nysseńczyka termino-

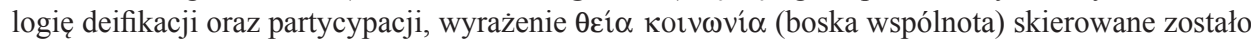
przez Grzegorza na związek istniejący między Bogiem a człowiekiem i stanowi nawiązanie do ter-

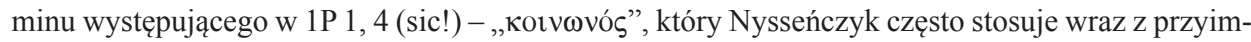

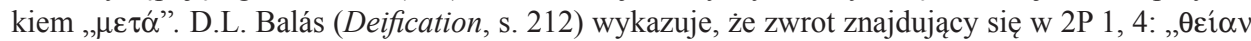

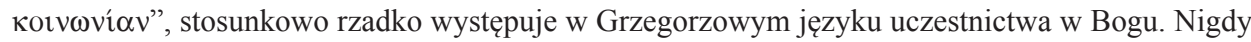
jednak ten tekst biblijny nie jest w pełni przytaczany w pismach Biskupa Nyssy, być może w celu uniknięcia błędnego wyobrażenia partycypacji stworzeń w transcendentnej naturze Boga. Szerzej na temat problemu cytacji 2P 1, 4 w świetle bizantyjskiego nauczania o deifikacji zob. Russell, The doctrine of deification, s. 232.

${ }^{108}$ Por. Szczerba, A Bóg będzie wszystkim we wszystkim, s. 229.

${ }^{109}$ Por. Russell, The doctrine of deification, s. 232.

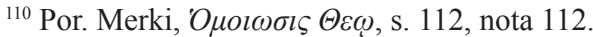

${ }^{111}$ Por. Strękowski, Sofiologia św. Grzegorza, s. 188; Rother, Gottverähnlichung, s. 513. 
nicowanym kontekście. Dlatego też, jak zauważa N. Russel1 ${ }^{12}$, w twórczości Biskupa Nyssy możemy mówić o trzech znaczeniach deifikacji. Pierwsze z nich, wyrażające misterium przybrania natury ludzkiej przez Syna Bożego, dotyczy zastosowania pojęć dotyczących przebóstwienia w sposób dosłowny, wyrażając deifikację jako całościowo zrealizowany proces dokonany w obszarze człowieczeństwa Jezusa Chrystusa. Znaczenie drugie stanowi poszerzenie idei deifikacji przez odniesienie jej do wymiaru sakramentalnego, dzięki któremu człowiek otrzymuje udział w przebóstwionym ciele Chrystusa. Oprócz tego, wyrażając deifikację w sensie metaforycznym, Nysseńczyk stosuje ją, aby podkreślić uczestnictwo człowieka w boskości i określić cel nieskończonego procesu $\dot{\varepsilon} \pi \dot{\varepsilon} \kappa \tau \alpha \sigma ı$.

W pismach Grzegorza z Nyssy zaprezentowana została oryginalna koncepcja życia duchowego, której cel prowadzi do jak najwierniejszego odbicia w całościowo pojętej naturze ludzkiej Obrazu Bożego (por. Rdz 1, 26; Kol 1, 15). Cel ten, ku któremu człowiek może się zbliżać jedynie na drodze niekończącej się wędrówki procesu ċ $\pi \dot{\kappa} \kappa \tau \alpha \sigma \iota \varsigma$, nigdy nie osiągnąwszy mety swych pragnień, wiąże się z doktryną przebóstwienia, którą Nysseńczyk kreśli w sposób niezwykle wyraźny i świadomy, posługując się przemyślanymi

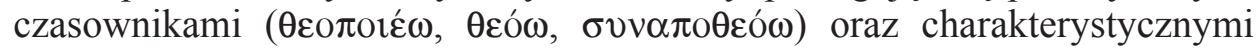
wyrażeniami, mającymi uwydatnić dynamizm zmiany ludzkości w bardziej

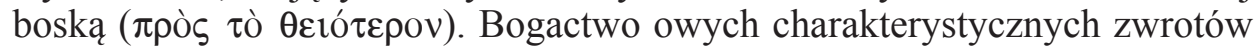
oraz wyważone użycie czasownikowych pojęć deifikacji wskazuje na pewną trudność, z którą na własny sposób zmierzył się Grzegorz, chcąc pogodzić wczesnochrześcijańskie podstawy doktryny przebóstwienia z zachowaniem zasad teologii apofatycznej. Dlatego też w całym dorobku Nysseńczyka pominięta została rzeczownikowa nazwa deifikacji, a sam opis przebóstwienia zostaje zestawiony z innymi, niewątpliwie ortodoksyjnymi, kategoriami relacyjności oddającymi zależność między Bogiem a człowiekiem, takimi jak adopcyjne usynowienie, pokrewieństwo z Bogiem, zamieszkanie w Bogu, czy

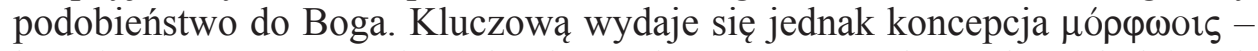
kształtowania natury człowieka, która dostarcza Kapadocczykowi kolejnych

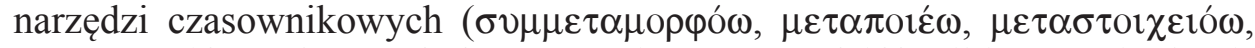
$\mu \varepsilon \tau \alpha \sigma \kappa \varepsilon v \alpha ́ \zeta \omega)$, służących do wyrażenia progresu deifikacji i stanowi właściwy kierunek rozwoju całościowo pojętej natury ludzkiej, co odpowiadać może Arystotelesowskiej $\dot{\varepsilon} \nu \tau \varepsilon \lambda \dot{\varepsilon} \chi \imath$.

Analiza opisów, w których Grzegorz nawiązuje do terminologii przebóstwienia, wykazała ściśle chrystocentryczny wymiar deifikacji, bowiem proces ten nie może dokonać się bez udziału przyczyny sprawczej i wzorczej,

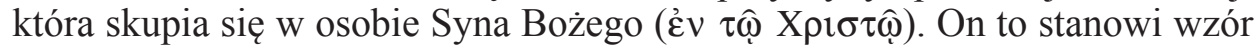

${ }^{112}$ Por. Russell, The doctrine of deification, s. 225-229. 
przebóstwienia, przez całościowe wypełnienie owego dynamizmu w swej ludzkiej naturze oraz ukazuje pełny Obraz Boży, do którego człowiek ma się upodabniać, a jako prawdziwy Bóg, posiada moc podniesienia pleromy ku temu, co bardziej boskie. Dzięki włączeniu się w ludzką monadę przez misterium wcielenia i wyniesienia jej w egzaltacji chwały zmartwychwstania, Chrystus stanowi również przyczynę sprawczą, ofiarowując ludzkości, za pośrednictwem działania właściwego Duchowi Świętemu, obiektywnie dokonany proces deifikacji.

Ujmując przebóstwienie w kontekście całościowo pojętej natury ludzkiej Grzegorz wskazuje na kolektywny wymiar owego procesu. Takie naświetlenie omawianego problemu pozwala jaśniej zobrazować sedno przebóstwienia: to nie ludzie dzięki rozwijaniu w sobie cnót, wskazań błogosławieństw ewangelicznych, czy cech właściwych Bogu, bądź przyjmujący sakramentalne Ciało Chrystusa, stają się bogami, co równać by się mogło z wielobóstwem, lecz „W wielu staje się jeden Bóg”. Stąd cała ludzkość stanowi właściwy obszar deifikacji, aż do pełnego otwarcia swej natury na jednego, prawdziwego Boga, sama zaś staje się coraz bardziej teoforyczna.

Chcąc zachować apofatyczny charakter nauczania Grzegorz w swoich dojrzałych pismach coraz częściej rezygnował z posługiwania się terminologią przebóstwienia na rzecz opisu partycypacji człowieka w naturze Boskiej. Taka alternatywa pozwoliła mu na zachowanie ortodoksji, a także poszerzyła rozumienie deifikacji, która dzięki ontycznemu wymiarowi partycypacji, daje możliwość do wyszczególnienia konkretnych zmian w naturze człowieka, który dzięki uczestnictwu w przymiotach należących wyłącznie i pierwszorzędnie do Boga, może nabierać boskich cech dzięki łączności z Bogiem w obrębie unii energetycznej, nie naruszając przy tym Jego świętej i transcendentnej istoty. Dzięki tak realistycznemu ukazaniu zmian zachodzących w naturze ludzkiej, człowiek rzeczywiście zmierza ku boskości, nigdy jednak nie stając się Bogiem.

\author{
"MAN TURNS INTO GOD". \\ THE TERMINOLOGY OF DEIFICATION \\ IN THE WRITINGS OF GREGORY OF NYSSA
}

\title{
(Summary)
}

Gregory of Nyssa presents the conception of human deification in an extraordinarily clear and concious way, using special verbs ( $\theta \varepsilon \circ \pi \mathrm{o} \varepsilon \dot{c} \omega, \theta \varepsilon o ́ \omega, \sigma v v \alpha \pi \mathrm{o}-$ $\theta \varepsilon o ́ \omega)$ and characteristic expressions to emphasize the dynamism of the change

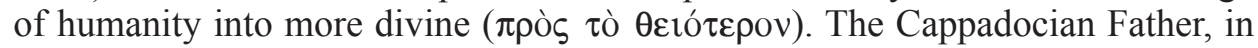
order to maintain the apophatic nature of his doctrine, more and more often rejects the term of deification and describes it in his writings as participation of man in 
the divine nature, therefore the nominal term of deification never occurs in his literary works. However, the analysys of Gregory of Nyssa's descriptions in which he refers to the terminology of deification has revealed a precisely chrystological and collective dimension of this process, which is possible to be taken up by man only owing to the energetic union connecting God and the world.

Key words: deification, participation, christological doctrines, sacramental life of Church, the energetic union.

Slowa kluczowe: przebóstwienie, uczestnictwo, doktryna chrystologiczna, sakramentalne życie Kościoła, unia energetyczna. 
